\title{
Vaikų astmos ambulatorinio gydymo problemos ir ypatumai
}

\author{
Jolanta Kudzyte் \\ LMSU MA Vaikų ligụ klinika
}

Reikšminiai žodžiai: astma, gydymas, vaikai, švokštimas.

Santrauka. Dažniausiai astma prasideda anksti vaikysteje, jos eiga kinta, keičiasi fenotipai, liga gali progresuoti arba įvykti remisija. Astmą gydyti vaikams labai sudètinga, nes jų kvèpavimo organai auga ir vystosi, bręsta imuninè sistema, vyksta natūrali eiga. Vaikų astmos diagnostika sunki ir paini, sudètinga skirti vaistų, o kūdikių atsakas i gydymą esti skirtingas ir dažnai nenuspèjamas.

\section{LIGOS EIGA}

Astma - dažniausia vaikų lètinẻ apatinių kvẻpavimo taku liga pasaulyje. Prasideda anksti vaikysteje, jos eiga kinta, keičiasi fenotipai, liga gali progresuoti arba ịvykti remisija. Populiacijos tyrimai rodo, kad maždaug 1 iš 3 vaiku iki trejų metụ patiria bent vieną švokštimo epizodą. Sulaukus šešerių metų švokštimas būna pasireiškęs 50 proc. vaikų.

Nors ilgalaikių studijų duomenimis, 25 proc. vaikų, kuriems buvo nuolatinè astma, švokšti pradèjo iki 6 mėn. amžiaus, o 75 proc. - iki 3 metų, pusei vaikų, hospitalizuotụ dèl sunkaus švokštimo epizodo iki $2 \mathrm{~m}$. amžiaus, nebuvo simptomų sulaukus $5 \mathrm{~m}$. amžiaus, 70 proc. - sulaukus $10 \mathrm{~m}$.

Vaikų astma sukelia daugiau problemų nei suaugusiụjų, nes:

- nesubrendusi imuniné ir kvépavimo taku sistema;

- sunku diagnozuoti (negalima tirti plaučiu funkcijos ir t. t.);

- kinta natūrali ligos eiga;

- yra apribojimu skirti vaistus;

- kitoks, kartais nenuspejjamas atsakas i gydymą;

- gydant turi būti kreipiamas dèmesys i vaiko amžių: kūdikiu atsakas i gydymą nepakankamas ir nepastovus, o paaugliai dažniausiai nesilaiko gydymo režimo.

Švokštimą ikimokyklinukams gali sąlygoti įvairios ligos, o beveik pusei patyrusiụjų švokštimą simptomai išnyksta pradejjus lankyti mokyklą, nesvarbu, kuo jie buvo gydyti. Simptomai dažniau visą gyvenimą išlieka, jei yra atopija ir jei jie sunkesni.

Astmą kontroliuoti vaikams labai sudètinga, nes auga ir vystosi kvépavimo organai, bręsta imuninè sistema, vyksta natūrali eiga. Vaiku astmos diagnostika sunki ir paini, sudètinga skirti vaistų, kūdikių atsakas i gydymą esti skirtingas ir dažnai nenuspejjamas.

Gydymo parinkimui ir diagnostikai labai svarbu vaiko amžiaus tarpsnis: iki 2-3 m. astma vadinama kūdikių, paauglystëje - paaugliu astma, o atlikti tyrimai rodo, jog atsakas i gydymą ir simptomai keičiasi 5 ir 12 gyvenimo metais (1 pav. ).
Kai kurie autoriai rekomenduoja astmą gydyti atsižvelgiant i provokuojančiuosius veiksnius, pagal astmos fenotipus, o ju vaikystèje yra labai daug (2 pav.). Tačiau dažniausiai tiek alerginès, tiek nealerginès astmos simptomus vaikams provokuoja virusiné infekcija.

Astma vaikysteje gali persistuoti, įvykti remisija ar vèl atsinaujinti. Labai svarbu, kad daugelis vaikų nustoja švokšti tam tikrais amžiaus tarpsniais. Nors didžioji dalis vaikų, kurie pradèjo švokšti iki 3 metų amžiaus, nustoja švokšti būdami šešerių, tačiau žinoma, jog šešiamečiu plaučių funkcija pradeda blogèti, ypač jei jie švokšti pradèjo iki 3 metų.

Astmą numatančio indekso (API) pagrindiniai didieji kriterijai yra astma sergantys tèvai ir vaikui diagnozuotas atopinis dermatitas, o mažieji - eozinofilija kraujyje, švokštimas neperšalus bei vaikui diagnozuotas alerginis rinitas. Teigiamas indeksas prognozuoja persistuojantị švokštimą šešiamečiams, kurie protarpiais švokšdavo iki 3 metu amžiaus. Kiti autoriai teigia, jog kūdikiai,

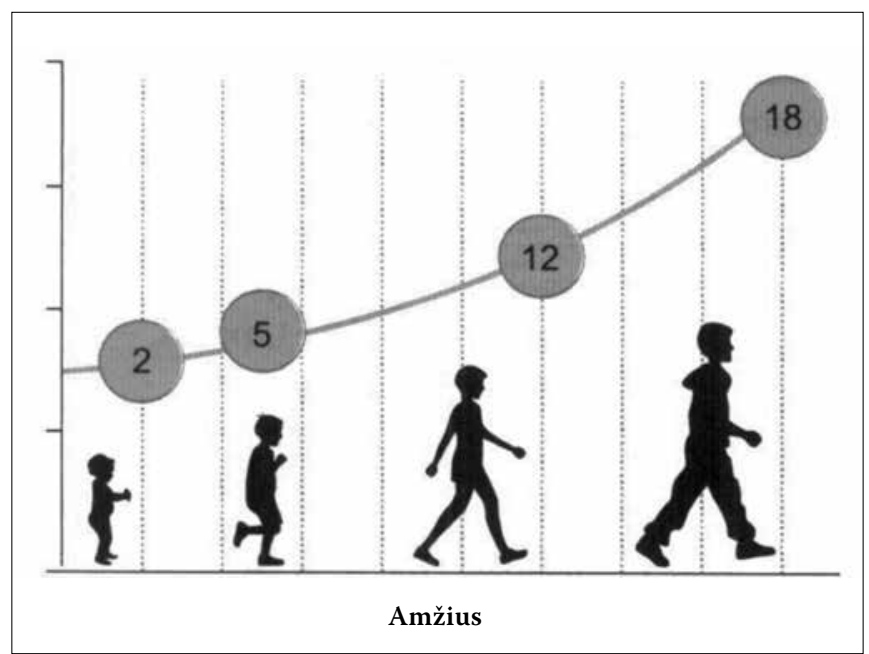

1 pav. Svarbiausi vaikų amžiaus tarpsniai astmai gydyti ir diagnozuoti 


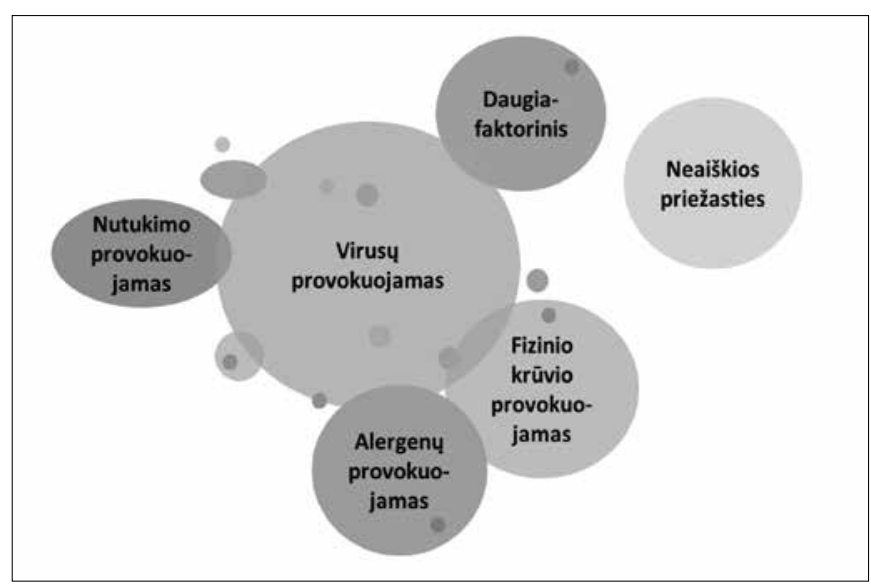

2 pav. Vaiku astmos fenotipai

kurie protarpiais švokščia, turi didesnę riziką susirgti astma paauglysteje, ypač jei yra atopija.

Diagnozuojant astmą, daugiausia dèmesio kreipiama $\mathfrak{i}$ švokštimo epizodų kartojimąsi. Nors nèra griežtai nurodoma, kiek turètų būti epizodų, tačiau siūloma, jog būtų ne mažiau kaip 3 kartai. Svarbus yra ne tik švokštimo pasikartojimas, bet ir kosulio, dusulio, krūtinès spaudimo, provokuojamų įvairių veiksnių, kaip antai: iritantų (šalčio, tabako dūmų), alergenų (naminių gyvūnų, žiedadulkių), kvèpavimo takų infekcijų, fizinio krūvio, verkimo, juoko, kartojimasis vidurnakti ar paryčiui. Labai svarbu vaiko atopija ir atopinè šeimos anamnezè. Spirometriją rekomenduojama pradèti atlikti 5-7 metuc vaikams. Kvėpavimo takų hiperreaktyvumo tyrimą, inhaliuojant metacholiną, histaminą, manitolį, hipertoninį druskos tirpalą ar šaltą orą, plačiai taikomą suaugusiųjų astmai diagnozuoti, vaikams rekomenduojama skirti atsargiai, nes nėra standartų pagal vaikų amžių ir svorį.

NO matavimas iškvepiamame ore gali būti naudingas eozinofilino uždegimo žymuo tiek diagnozuojant, tiek ir stebint atsaką i̇ gydymą gliukokortikoidais.

Daugelis metodinių rekomendacijų pripažista, jog sunkiausia astmą diagnozuoti 2-3 metų vaikams. Jei jiems ịtariama astma, galima skirti 3 ménesių gydymą inhaliuojamaisiais gliukokortikoidais (IGK). Jei gydant simptomai išnyksta, o gydymą baigus jie vèl atsinaujina, galima diagnozuoti astmą. Nors neigiamas méginys astmos buvimo taip pat negali paneigti.

Vaikų astma neretai mėgdžioja kitas ligas, tačiau nereti ir atvirkštiniai atvejai. Švokštimas yra vienas dažniausių kvėpavimo takų ligu simptomas vaikystejje, o jị sukelti gali daugelis ligų (1 lentelè). Kūdikystèje bronchiolitas būna dažniausia švokštimo priežastis, tačiau ji sukelti gali ir kitos ūminès ligos, taip pat igimtos anomalijos ar genetinès ligos. Dažniausiai švokščia 1-3 metų vaikai. Vyresnio amžiaus vaikų grupèje astma dažnèja, didejjant vaiko amžiui. Švokštimo „piką" pirmaisiais gyvenimo metais lemia siauri kvėpavimo takai (ypač neišnešiotų naujagimių), greitai paburkstanti gleivinè ir jos polinkis i hipersekreciją. Švokštimą dažniausiai paskatina respiracinis sincitijaus, gripo, paragripo virusai, mikoplazmos bei chlamidijos.

Du trečdaliai švokščiančių vaikų švokščia tik iki 1-3 metuc ir vèliau nustoja, o likęs trečdalis suserga astma.
1 lentelè. Vaiku švokštimo priežastys

\begin{tabular}{|c|c|}
\hline $\begin{array}{l}\text { Ūminis švokštimas } \\
\text { - } \quad \text { Obstrukcinis bronchitas } \\
\text { - } \quad \text { Bronchiolitas } \\
\text { - } \quad \text { Pneumonija } \\
\text { - Astma } \\
\text { Pasikartojantis švokštimas } \\
\text { - Kartotinių virusinių } \\
\text { infekcijų sukeltas } \\
\text { švokštimas } \\
\text { Astma } \\
\text { Nuolatinis švokštimas } \\
\text { - Persirgus paprastu } \\
\text { bronchiolitu } \\
\text { Obliteracinis } \\
\text { bronchiolitas } \\
\text { Astma }\end{array}$ & 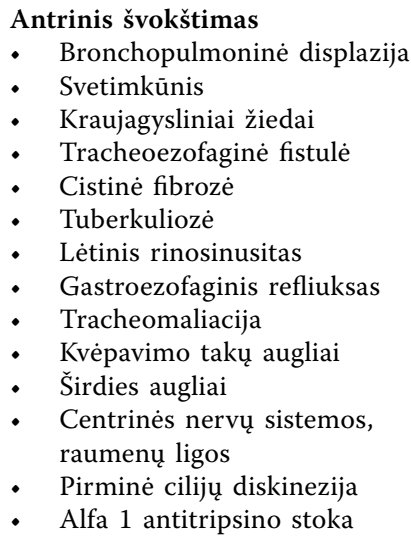 \\
\hline
\end{tabular}

Kadangi beveik visi astma sergantys vaikai pradeda švokšti iki vienerių metų, labai sunku atskirti, kuriais atvejais švokštimas rodo astmos pradžią. Sąlyginai visi vaikai pagal švokštimo pobūdị skirstomi ị du pogrupius - virusų provokuojamą mažų vaikų ir daugiafaktorinị švokštimą.

Vis labiau aiškejja pasyvaus rūkymo žala vaikams. Rūkančių mamų kūdikiai 4 kartus dažniau švokščia pirmaisiais gyvenimo metais, o jų plaučių funkcija jau būna sutrikusi iškart po gimimo.

Taigi kūdikiams ir ikimokyklinio amžiaus vaikams astma diagnozuojama tik ịvertinus anamnezès, klinikinių ir laboratorinių tyrimų duomenis, nes šio amžiaus vaikų plaučių funkcijos tyrimas dažniausiai būna nekokybiškas, o rezultatai - nepatikimi. Mokyklinio amžiaus vaikams vertinami plaučių funkcijos rodmenys.

\section{ASTMOS KONTROLE்}

Svarbiausias astmos valdymo veiksnys - medikamentinis gydymas, tačiau būtinas vaiko ir tèvų mokymas, specifinių ir nespecifinių dirgiklių bei rizikos veiksnių vengimas. Dẻl nuolat kintančios astmos eigos, privalomas nuolatinis vaiko klinikinès būklès vertinimas ir stebėsena. Išsiaiškinus „kaltạjił“ alergeną, galima alergenui specifinè imunoterapija vaikams nuo 5 metų.

Kai kurie mokslininkai siūlo specifini gydymo būdą pagal fenotipą, tačiau šiam metodui pagristi dar stinga mokslinių įrodymų. Gydymo tikslas - išvengti astmos paūmèjimų. Anksčiau buvo manoma, kad anksti pradètas gydymas gali pakeisti natūralią astmos eigą, bet pastarųjų metų moksliniais tyrimais nustatyta, kad net anksti pradètas gydymas IGK, nepaisant visų teigiamų šio metodo savybių, to padaryti negali.

Vienose metodinèse rekomendacijose rekomenduojama gydymą skirti atsižvelgiant ị astmos sunkumą, kitose i kontrolès lygmenị, o dar kitose siūloma atsižvelgti ir i sunkumą, ir kontrolès lygmenį.

Ivertinus paciento būklę, skiriamas pakopinis astmos gydymas pagal astmos kontrolès lygmeni nepamirštant galimos rizikos (2 lentelè).

Jei astma nesuvaldoma per 1-3 mèn., rekomenduojama skirti aukštesnès pakopos gydymą, prieš tai patikrinus, kaip vartojamos tarpinès, ar nepakito aplinkos poveikis, 
2 lentelè. Astmos kontrolès lygmenys

\begin{tabular}{|c|c|c|c|c|c|}
\hline \multirow[t]{5}{*}{ Pokyčiai } & Klinikiniai požymiai & $\begin{array}{l}\text { Visiškai } \\
\text { kontroliuojama }\end{array}$ & Kontroliuojama & $\begin{array}{l}\text { Iš dalies } \\
\text { kontroliuojama }\end{array}$ & Nekontroliuojama \\
\hline & Simptomai dieną & Nèra & $\leq 2$ per sav. & $>2$ per sav. & Nuolat \\
\hline & $\begin{array}{l}\text { Bronchus plečiančių vaistų var- } \\
\text { tojimo simptomams šalinti (sku- } \\
\text { baus gydymo) atvejų skaičius }\end{array}$ & Nereikia & $\leq 2$ per sav. & $>2$ per sav. & Kasdien \\
\hline & Fizinio aktyvumo ribotumas & Nèra & Nèra & Neženklus & Labai ženklus \\
\hline & $\begin{array}{l}\text { Plaučių funkcija (PEF ar FEV }{ }^{1} \text { ) } \\
\text { normos ar individualaus geriau- } \\
\text { sio rodiklio }\end{array}$ & $>80$ proc. & $\geq 80$ proc & $60-80$ proc. & $<60$ proc. \\
\hline \multirow[t]{2}{*}{ Rizika } & Paūmèjimai per metus & 0 & 1 & 2 & $>2$ \\
\hline & Nepageidaujamas vaistų poveikis & Nèra & Nèra & Gali būti ne nuolat & Gali būti ne nuolat \\
\hline
\end{tabular}

ar gydomos gretutinès ligos (pvz., alerginis rinitas). Jei liga gerai kontroliuojama 3 mèn., galima skirti žemesnès pakopos gydymą

Pakopinio gydymo principai (3 pav.):

- 1 pakopa. Skiriamas vienas iš uždegimą slopinančių vaistu - nedidelè inhaliuojamojo gliukokortikoido (IGK) dozè arba leukotrienų receptorių antagonistas (LTRA). LTRA dažniau skirtinas mažiems vaikams (mažesnis nepageidaujamas poveikis, lengviau vartoti tabletes), o IGK - vyresniems, atopiškiems.

- 2 pakopa. Vyresniems nei $5 \mathrm{~m}$. vaikams rekomenduojama prie IGK pridèti IVBA (ilgai veikiantị beta 2 agonistą) arba didinti IGK dozę iki vidutinès, o mažesniems nei 5 metai - didinti IGK dozę iki vidutinès arba pridèti LTRA.

- 3 ir 4 pakopos. Toliau didinama IGK dozè ir papildomai skiriama IVBA, LTRA.

- 5 pakopa. Prie esamo gydymo pridedamas geriamasis gliukokortikoidas ir anti IgE omalizumabas.

\section{Vaistai ir vartojimo būdas}

Astmai gydyti skirti vaistai gali būti vartojami naudojant dozuotus aerozolio inhaliatorius (DAI), dozuotus milteliu inhaliatorius (DMI) ar srovinius purkštuvus (3 lentelè).

Tarpinès leidžia aerozolio inhaliatorius vartoti kūdikiams, mažiems vaikams, taip pat pacientams, kurie nesugeba suderinti vaistų ịpurškimo su ịkvejpimu. Be to, tarpinès pagerina vaistu patekimą i plaučius, mažiau dirgina gerklę, mažiau vaistu rezorbuojasi burnoje, rečiau sukelia vietinị nepageidaujamą poveikị (burnos kandidozę, balso prikimimą), taip pat ir sistemini poveikị. Todèl jos vartotinos ir vyresnių vaikų. Jei vartojami inhaliuojamieji milteliai, po inhaliacijos būtina gerai išskalauti burną, kad sumažètų vaisto rezorbcija burnoje.

Inhaliuojamieji gliukokortikoidai yra patys veiksmingiausi kontroliuojamieji vaistai gydant astma sergančius ìvairaus amžiaus vaikus. Daugumos vyresnių nei $5 \mathrm{~m}$. vaikų klinikiniai simptomai ir plaučiu funkcija pagerèja gydant mažomis ar vidutinėmis IGK dozemis (100-200 $\mu \mathrm{g}$ per parą). Kartais paros dozę tenka padidinti iki $400 \mu \mathrm{g}$, norint pasiekti astmos kontrolę ar apsaugoti nuo fizinio krūvio sužadinamų astmos simptomų. Simptomai sumažèja ir plaučių funkcija pagerejja po 1-2 savaičių gydymo kurso, tačiau kvėpavimo takų reaktyvumas sumažèja tik gydant keletą mènesių. Būklei pagerèjus, dozė turi būti mažinama iki mažiausios efektyvios (4 lentelè).

Gydant jaunesnius nei $5 \mathrm{~m}$. vaikus, labai svarbu parinkti tinkamą tarpinę ir mokyti taisyklingos vaistų įkvėpimo technikos. Daugumos tokio amžiaus vaikų astmą kontroliuoti pavyksta gydant $200 \mu \mathrm{g}$ ar mažiau budezonido ar ekvivalento per parą.

Nuolatinis mažų IGK dozių vartojimas dažniausiai neapsaugo nuo virusų skatinamo švokštimo epizodų kartojimosi.

Nors IGK vartojančių vaikų ūgis kartais iki paauglystès esti mažesnis, bet suaugę jie būna normalaus ūgio. Nepageidaujamo poveikio vaikų nervų sistemai, kataraktai, dažnesnèms kvẻpavimo takų infekcinèms ligoms nepastebèta. Dantų èduonis labiau sietinas su beta 2 agonistų inhaliavimu, mažinančiu burnos pH, o ne su IGK. Jei kartu gydomas alerginis rinitas ar atopinis dermatitas, visada reikia apskaičiuoti vaiko gaunamą suminę gliukokortikoidų dozę.

Geriamieji gliukokortikoidai. Dèl stipraus nepageidaujamo poveikio geriamieji gliukokortikoidai vaikams skiriami tik astmos paūmejjimo metu ar esant virusu sukeltam švokštimui. Gydymo kurso trukmè - 3, 5, $10 \mathrm{~d}$.

Leukotrienų receptorių antagonistai (LTRA) sumažina klinikinius astmos simptomus vyresniems nei $5 \mathrm{~m}$. vaikams, bet uždegimą slopinantis šių vaistų poveikis yra silpnesnis

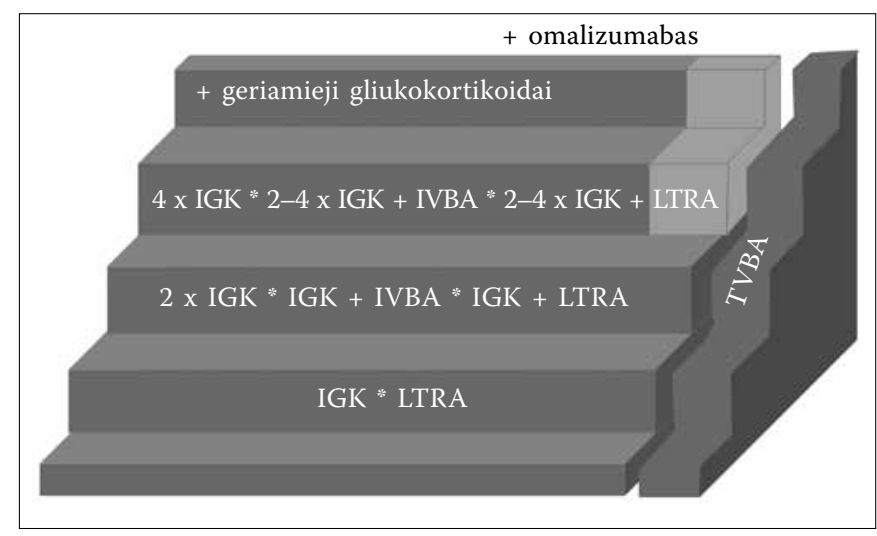

3 pav. Astmos pakopinis gydymas 
3 lentelè. Inhaliuojamojo prietaiso parinkimas vaikams

0-5 metai

- DAI su tarpine ir veido kauke (arba kandikliu kai tik vaikas gali ji naudoti)

Daugiau kaip 5 metai

- DAI su tarpine ir kandikliu

arba

- DMI

arba

- Kvejpavimu ijungiamas DAI

Srovinis purkštuvas - alternatyvus gydymo metodas bet kurio amžiaus vaikams

Neturint tarpinès - galima naudoti $500 \mathrm{ml}$ plastikinį buteli

nei mažų IGK dozių. LTRA mažina fizinio krūvio sužadinamus astmos simptomus. Jụ galima skirti kaip papildomą gydymą, jei gydant mažomis IGK dozėmis nèra pakankamo efekto ar dar greta pacientas serga alerginiu rinitu. Nurodoma, jog šis derinys suretina astmos paūmèjimus.

Jaunesniems nei $5 \mathrm{~m}$. vaikams LTRA retina virusu sukeliamus astmos paūmèjimus.

Ilgai veikiančių inhaliuojamųjų beta 2 agonistų (IVBA) poveikis jaunesniems nei $5 \mathrm{~m}$. vaikams dar nepakankamai ištirtas. Vyresniems nei $5 \mathrm{~m}$. vaikams IVBA skiriami tik kartu su IGK. Šiuos vaistus rekomenduojama skirti tada, kai nèra pakankamo efekto gydant mažomis IGK dozėmis. Toks derinys pagerina PEF ir kitus plaučių funkcijos rodiklius, tačiau nesuretina astmos paūmèjimų.

Trumpai veikiantys beta 2 agonistai (TVBA) pradeda veikti per keletą minučiu, todèl salbutamolis yra pirmos eilès bronchus plečiantis vaistas bet kurio amžiaus vaikams. Inhaliuojamieji TVBA sukelia gerokai lengvesni nepageidaujamą poveikị (drebuli, padidejusi dirglumą, galvos skausmą) nei geriamieji. Geriamieji TVBA vaikams neturètų būti skiriami. Fizinio krūvio sužadinamų simptomų padeda išvengti tik inhaliuojamieji beta 2 agonistai; geriamiesiems toks poveikis nebūdingas.

Anticholinerginiai vaistai rekomenduojami tik mažiems vaikams bei trumpalaikiam gydymui astmos paūmejimo atvejais, nes sustiprina salbutamolio poveiki.

\section{ASTMOS PAŨMĖJIMO GYDYMAS}

Astmos paūmèjimas - ūmus ar poūmis vis labiau ryškejjančiuc astmos simptomų, susijusių su kvejpavimo takų obstrukcija, epizodas. Paūmèjimas gali būti lengvas, vidutinis, sunkus ir labai sunkus. Tokia klasifikacija sunkiai pritaikoma kūdikiams ir ikimokyklinukams, nes negalima atlikti plaučių funkcijos tyrimų. Bronchus plečiantys vaistai - astmos paūmejjimo gydymo pagrindas. Jais gydymą reikia pradèti namuose, tęsti prièmimo skyriuje. Rekomenduojama inhaliuoti salbutamoli, po 2-10 paspaudimu (200-1000 $\mu \mathrm{g})$ kas 20 min 3 kartus pirmą valandą, o po to pagal poreikị. Labai efektyvūs yra geriamieji gliukokortikoidai, ypač jei skiriami iškart astmai paūmėjimus. Rekomenduojama dozė $-1-2 \mathrm{mg} / \mathrm{kg}$ per parą (iki $20 \mu \mathrm{g}$ vaikams, jaunesniems nei $2 \mathrm{~m}$., ir iki $60 \mu \mathrm{g}$ - vyresniems). Gydyti reikètu 3-5 dienas. Esant hipoksemijai, svarbu skirti deguonies palaikant jo saturaciją didesnę nei 95 proc. Ipratropimobromidas gali palengvinti simptomus,

\begin{tabular}{lc}
4 lentelè. Inhaliuojamujų gliukokortikoidų dozės \\
\hline IGK & Maža paros dozė (mg) \\
Beklometazonodipropionatas & 100 \\
Budezonidas & 100 \\
Ciklezonidas & 80 \\
Flunizolidas & 500 \\
Flutikazonopropionatas & 100 \\
Mometazonofuroatas & 100 \\
Triamcinolonas & 400
\end{tabular}

Vidutinès dozès yra visados dvigubos $(2 \mathrm{x})$

Didelès dozès yra 4 kartus didesnès $(4 \mathrm{x})$, išskyrus flunizolido ir triamcinolono, kurių dozès yra trigubos $(3 \mathrm{x})$

vartojamas kartu su salbutamoliu, ypač mažiems vaikams ar esant sunkiam astmos paūmèjimui. Inhaliuoti reikia po 2-8 paspaudimus kas 20 min. 3 kartus.

Labai didelès IGK dozès gali būti taip pat skirtos astmai paūmèjus, bet tai mažiau efektyvus būdas nei geriamieji gliukokortikoidai. Nèra įrodymų, kad $\mathrm{Na}$ montelukastas būtų efektyvus gydant astmos paūmèjimus. Jei būklè toliau blogejja, vaiką reikia hospitalizuoti.

\section{ASTHMA OUT PATIENT TREATMENT IN CHILDREN: PROBLEMS AND SPECIFICITY}

\section{JOLANTA KUDZYTE \\ DEPARTMENT OF CHILDREN DISEASES \\ LITHUANIAN UNIVERSITY OF HEALTH SCIENCES}

Keywords: asthma, children, guidelines, treatment, wheeze.

Summary. Asthma most often start searly in life and hasvariable courses and unstable phenotypes which may progress or remit over time. In children asthma often presents with additional challenges not all of which are seeninadults, because of the maturing ofther espiratory an immune systems, natural history, scarcity, difficulty in establishing the diagnosis and delivering medications, and a diverse and frequently unpredictable response to treatment.

\section{LITERATŪRA}

1. Papadopoulos NG, Arakawa H, Carlsen KH. Inernational consensuson (ICON) pediatric asthma. Allergy. 2012 Aug; 67(8):976-97.

2. Lotvall J, Pawankar R, Wallace DV, Akdis CA, Rosenwasser LJ, Weber RW, et al. Wecallfori CAALL: International Collaborationin Asthma, Allergy and Immunology. Allergy 2012; 67:449-450.

3. Fromthe Global Strategy for Asthma Management and Prevention. Global Initiative for Asthma (GINA), 2011. Availablefrom: http://www. ginasthma. org.

4. From the Global Strategy for the Diagnosis and Management of Asthma in Children 5 Years and Younger. Global Initiative for Asthma (GINA), 2009. Availablefrom:http://www. ginasthma. org/.

5. Bacharier LB, Boner A, Carlsen KH, Eigenmann PA, Frischer T, Gotz M, et al. Diagnosis and treatment of asthma in childhood: a PRACTALL consensus report. Allergy 2008;63:5-34.

6. British Thoracic Society and Scottish Intercollegiate Guidelines Network. British Guideline on the Management of Asthma: A National Clinical Guideline. British Thoracic Society and Scottish Intercollegiate Guidelines Network, 2011. Available from: http://www. sign. ac. uk/guidelines/fulltext/101/index. html.

7. Martinez FD. New insights into the natural history of asthma: primary prevention on the horizon. J Allergy Clin. Immunol. 2011;128:939-945.

8. Busse WW, Lemanske RF Jr. Asthma. N Engl J Med 2001;344:350-362. 